\title{
Churches: Lasting Sources of Civic Engagement? Effects of Secularization and Educational Expansion on Non-religious Volunteering in the Netherlands, 1988 and 2006
}

\author{
Paul Vermeer ${ }^{1} \cdot$ Peer Scheepers $^{2} \cdot$ Manfred te Grotenhuis $^{3}$
}

Published online: 19 January 2016

(c) The Author(s) 2016. This article is published with open access at Springerlink.com

\begin{abstract}
During the last three decades Dutch church attendance rates dropped considerably, while the relative share of volunteers in non-religious organizations decreased at a slower rate. This is an unexpected development given the positive association between religious involvement and volunteering. In this article, we try to account for this development by addressing the following question: Why has a massive and ongoing decline of church attendance in the Netherlands not resulted in a similar drop in the relative number of volunteers in non-religious voluntary organizations? In view of this question, we wonder if the negative effect of declining church attendance on volunteering is perhaps counterbalanced by a positive effect of educational expansion. Our findings reveal that this is indeed the case, but these counterbalancing effects are only modest.
\end{abstract}

Résumé Au cours des trente dernières années, les taux de fréquentation des églises hollandaises ont baissé considérablement, tandis que la part relative des bénévoles dans les organisations laïques a diminué à un rythme plus lent. Ce développement est inattendu étant donné l'association positive entre l'engagement religieux et le bénévolat. Dans cet article, nous tentons d'expliquer cette évolution en nous penchant sur la question suivante : Pourquoi la baisse massive et continue de la fréquentation des églises aux Pays-Bas n'a-t-elle pas entrainé une baisse similaire du nombre relatif de bénévoles dans les organismes bénévoles laïques ?

Paul Vermeer

p.vermeer@ftr.ru.nl

1 Empirical Study of Religion at the Faculty of Philosophy, Theology and Religious Studies, Radboud University, PO Box 9103, 6500 HD Nijmegen, The Netherlands

2 Comparative Methodology at the Faculty of Social Sciences, Radboud University, Nijmegen, The Netherlands

3 Statistics at the Faculty of Social Sciences, Radboud University, Nijmegen, The Netherlands 
Face à cette question, nous nous demandons si l'effet négatif de la baisse de fréquentation des églises sur le bénévolat peut être contrebalancé par un effet positif de l'expansion de l'éducation. Nos résultats révèlent que c'est effectivement le cas, mais que ces effets d'équilibrage sont modestes.

Zusammenfassung In den letzten drei Jahrzehnten war in den Niederlanden ein erheblicher Rückgang der Kirchenbesuche zu verzeichnen, während der Rückgang des relativen Anteils von Ehrenamtlichen in nicht religiösen Organisationen langsamer war. Dies ist eine unerwartete Entwicklung angesichts der positiven Assoziation zwischen religiösem Engagement und ehrenamtlicher Arbeit. In diesem Beitrag versuchen wir, diese Entwicklung zu erklären, indem wir auf folgende Frage eingehen: Warum hat der enorme und anhaltende Rückgang von Kirchenbesuchen in den Niederlanden nicht zu einem ähnlichen Rückgang der relativen Zahl von Ehrenamtlichen in nicht religiösen Freiwilligenorganisationen geführt? Im Hinblick auf diese Frage überlegen wir, ob der negative Effekt der abnehmenden Kirchenbesuche auf die ehrenamtliche Arbeit vielleicht durch einen postiven Effekt der Bildungsexpansion ausgeglichen wird. Unsere Ergebnisse zeigen, dass dies tatsächlich der Fall ist, die Ausgleichseffekte jedoch nur gering sind.

Resumen Durante las tres últimas décadas, las tasas de asistencia a la iglesia danesa han descendido considerablemente, mientras que la participación relativa de voluntarios en organizaciones no religiosas descendían a una tasa más lenta. Esto es un cambio inesperado dada la asociación positiva entre implicación religiosa y voluntariado. En el presente artículo, tratamos de responder a este cambio abordando la siguiente pregunta: ¿Por qué un descenso masivo y continuo de la asistencia a la iglesia en los Países Bajos no ha dado lugar a una caída similar en el número relativo de voluntarios en organizaciones voluntarias no religiosas? A la vista de esta pregunta, nos preguntamos si el efecto negativo de la descendente asistencia a la iglesia sobre el voluntariado queda compensado quizás por un efecto positivo de la expansión educativa. Nuestros hallazgos revelan que éste es, realmente, el caso, pero estos efectos de contrapeso son sólo modestos.

Keywords Civic engagement - Secularization - Church attendance · Education · Counterfactual analysis

\section{Introduction}

Volunteering in organizations and associations for the benefit of others is generally considered an important aspect of civic engagement. It is an expression of people's concern for the common good and an important indication of social capital, and more particularly of formal social capital (Pichler and Wallace 2007). But what kind of people do volunteer? Who are involved in all kinds of voluntary organizations and who refrain from volunteering? These questions have been addressed by many scholars, which has have resulted in the identification of various determinants of volunteering (cf. Wilson 2000, 2012 for overviews of the research literature 
available). Although many factors determine whether or not people get involved in voluntary action, one factor especially stands out: religious involvement. In several countries, religious involvement has been identified as an important determinant of volunteering for both religious as well as non-religious voluntary associations. This is for instance the case in the US (Jackson et al. 1995; Putnam 2000; Putnam and Campbell 2010), in Canada (Berger 2006; Perks and Haan 2011) as well as in various European countries (Reitsma 2007; Ruiter and De Graaf 2006; Savelkoul et al. 2011). In the Netherlands, the association between religious involvement and volunteering is also found (De Hart 1999), and according to Van Ingen and Dekker (2011), it has even become stronger between 1975 and 2005.

However, in the Netherlands, there is something odd to this relationship between religious involvement and volunteering. For several decades now, Dutch society has witnessed a massive and ongoing process of secularization (Becker and De Hart 2006); a process that especially began to accelerate in the early seventies of the last century. In 1966, half of the Dutch population aged 17 or older attended church almost every week, and this dropped to a mere $16 \%$ in 2006 (Bernts et al. 2007, p. 17). Given the positive association between religious involvement and volunteering, one would expect a similar substantial drop in the relative share of volunteers over this period. Surprisingly, however, this has not happened. Dekker and Van den Broek (2005) for instance show a rise of volunteers in the Netherlands between 1981 and 2000. Only recent studies show, that this rise initially persisted after the turn of the century, but turned into a decline after 2008 (cf. Schuyt et al. 2011). However, even this modest decline is not in accordance with the massive decline of religious involvement, which leaves us with a puzzle. That is to say, a rather massive decline in religious involvement, i.e., church attendance, has as yet not resulted in a similar decline in involvement in voluntary organizations, despite the clear association between religious involvement and volunteering reported in various studies. Furthermore, comparing the Netherlands with other European countries reveals that the level of membership of and volunteering for voluntary associations is relatively high, while the level of religious involvement is among the lowest in the world (Gesthuizen et al. 2013).

In this study, we aim to offer an explanation for this puzzle by addressing the following research question: Why has the massive decline of church attendance in the Netherlands not resulted in a similar substantial decline in the relative number of volunteers in non-religious voluntary organizations? In view of this question, we will especially consider education as an alternative determinant of volunteering, next to religious involvement. In Dutch society, declining rates of church attendance are paralleled by a process of educational expansion. While church attendance has decreased during the past decades, the educational level of the Dutch population has increased considerably over the same period (Herweijer 2010). Since higher levels of individual educational attainment also foster volunteering (Gesthuizen 2006; Gesthuizen et al. 2008; Gesthuizen and Scheepers 2012; Wilson 2000; 2012), it is conceivable that the loss of volunteers due to secularization is in part counterbalanced by educational expansion.

As such this approach is not new, except for our explicit focus on volunteering for non-religious organizations. Previously, Van Ingen and Dekker (2011) also 
studied the possible counterbalancing effects of declining church attendance and educational expansion on volunteering in the Netherlands and found an increasing effect of church attendance, but a decreasing effect of education. However, in their study they did not clearly distinguish between volunteering for religious and nonreligious organizations, which may have affected their results. Since higher levels of individual educational attainment have a secularizing effect (De Graaf and Te Grotenhuis 2008), it would be highly unlikely to find that the higher educated become more involved in volunteering for religious organizations. Being aware of this, Van Ingen and Dekker in a subsequent analysis only considered volunteering for non-religious organizations and still found a positive effect of church attendance. Unfortunately, however, they did not perform such a subsequent analysis including the effect of education. So, the decreasing effect of education they report still concerns the effect of education on all kinds of volunteering, with no distinction between religious and non-religious volunteering. In order to study, whether there is a counterbalancing effect of educational expansion on volunteering, it is in our view more meaningful to consider volunteering for non-religious organizations.

A final introductory remark regards the specific time span of our study. To answer our research question, we use large-scale longitudinal data on volunteering for non-religious organizations, church attendance and education gathered in the Netherlands between 1988 and 2006. This period constitutes a unique time series in which information concerning volunteering was gathered with the help of comparable questions. Unfortunately, this changed after 2006, which is why we could not use more recent data in order to address our research question.

\section{Theory and Hypotheses}

Longitudinal developments in social activities like volunteering may have two kinds of determinants: changes in the behavior of specific groups and changes in the relative size of these groups. Below, we consider both determinants in relation to declining rates of church attendance and educational expansion and formulate four hypotheses which will be tested in this study.

\section{Changes in the Voluntary Behavior of Dutch Churchgoers}

The fact that the number of volunteers in non-religious organizations has decreased at a slower rate than the number of churchgoers may be due to an increasing involvement of religious people in volunteering. This would reflect a behavioral change within a specific group in the Dutch population: relatively more churchgoers engaged in non-religious volunteering over time.

Although this may seem strange from the perspective of secularization, one could argue that this is in fact a typical consequence of it. For instance, as Bruce (2003) contends, the only way religious communities may survive in an increasingly secular environment, is by strengthening the communities of like-minded and committed believers. Communities like these exhibit a certain strictness by 
demanding commitment from their members to religious beliefs and morals and also expect their members to proselytize and demonstrate their religious commitment in public (Kelley 1972). Indications for this are also present in the Netherlands. Reporting on developments in Dutch religious involvement, Becker and De Hart (2006) and De Hart (2014) show that younger cohorts of Dutch churchgoers, i.e., those born after 1960, are also more orthodox believers. Similarly, conducting a panel study into the relationship between belonging and believing among fortyyear-olds, Vermeer and Janssen (2011) found that those who remained loyal to their religious community over the years are also the most orthodox. Examples like these show that in a secular environment, religious communities not only become smaller, but at the same time also become more cohesive and homogeneous. Of course, this does not necessarily imply that more and more churchgoers become involved in volunteering, let alone in non-religious volunteering. Still, it is conceivable that churchgoers in secular societies, because they are part of more cohesive communities, will experience more peer pressure to volunteer in religious organizations, which again increases the odds that their religious voluntary actions spillover into non-religious volunteering. For the Netherlands, De Hart (2014) recently showed that there is indeed a strong spillover effect from religious into nonreligious volunteering, while Ruiter and De Graaf (2006), conducting a crossnational study into religion and volunteering, demonstrated that in secular societies religious people are more active in both religious and non-religious volunteering. This line of reasoning results in our first hypothesis: Over time the proportion of regular churchgoers who volunteer for non-religious organizations has increased in the Netherlands (H1). Consequently, on the macro level, this increasing level of civic engagement among those remaining loyal to their religious community may have worked as a compensator for the loss due to secularization (see $\mathrm{H} 3$ below).

\section{Changes in the Voluntary Behavior of the Highly Educated Dutch}

Not only churchgoers may increase their level of civic engagement over time, but the highly educated may get more involved as well. Again this can be explained in terms of network theory (Bekkers 2004). To begin with, highly educated people may be more prone to volunteer because they benefit from it, i.e., being involved in voluntary organizations might also be a confirmation of their social status (Gesthuizen et al. 2008). This is for instance stressed by Smith (1994), who refers to the dominant status model. This model implies that participation in voluntary organizations is more likely for individuals who occupy dominant roles and positions in society, like having higher status jobs, enjoying a higher income or having a higher education, because volunteering confirms their position and adds to their social prestige. Hence, civic involvement is likely to be an important social norm among the highly educated. But highly educated individuals are also more likely to interact with other highly educated individuals and to be part of social networks of like-minded individuals. Thus, since civic engagement is an important social norm among the highly educated, highly educated individuals are part of social networks that stimulate and reinforce their civic engagement (Gesthuizen et al. 2008; Van Ingen and Dekker 2011). So, if the proportion of highly educated 
increases, social networks of like-minded, highly educated individuals will become more dense, which in turn increases the odds that highly educated individuals will get requests and feel peer pressure to actually become more involved in voluntary organizations. Of course, this line of reasoning does not rule out that a ceiling effect is likely to occur if the proportion of higher educated individuals continues to grow. But a ceiling effect is unlikely when it comes to the period covered by our data in which no more than 35-40 \% of the Dutch population is expected to have a higher education or university degree (cf. also Herweijer 2010). On the basis of this expectation, it is plausible to assume that during this time frame the higher educated are probably still part of distinct social networks with specific civic norms. Summarizing this line of reasoning results in our second hypothesis: Over time the proportion of highly educated individuals who volunteer for non-religious organizations has increased in the Netherlands (H2). Consequently, on the macro level, this increasing level of civic engagement among the highly educated may have worked as a compensator for the effects of secularization (see H3).

\section{Changes in the Proportion of Regular Churchgoers in the Dutch Population}

As mentioned in the introduction, in Dutch society, a massive decline of church attendance has occurred. Consequently, the religious composition of the Dutch population has changed and currently comprises far less regular churchgoers than three of four decades ago. This may also affect the number of volunteers in nonreligious organizations.

According to Glock and Stark (1965), being religious not only involves upholding certain religious beliefs, but it may also relate to having experiences of transcendence, performing ritual practices, having knowledge about a specific religious tradition as well as to showing desired moral behavior. Religion is a multidimensional phenomenon, but research has shown that not all dimensions are equally relevant with respect to volunteering. On the contrary, especially church attendance is of importance here: collective or communal aspects of religion appear to be more important determinants of voluntary action than individual aspects. In the Netherlands, this was shown by Bekkers and Schuyt (2008) and Van Tienen et al. (2011). Why collective aspects of religion are particularly important in this respect is usually explained in terms of network theory (Bekkers 2004; Ruiter and De Graaf 2006). What matters is that religion brings people together in close-knit social networks in which engagement in voluntary work is a social norm to which religious people are supposed to conform. This explanation is underpinned by an often found decreasing effect of church attendance on volunteering for religious as well as non-religious organizations, once participation in religious social networks is taken into account (cf. for instance Becker and Dhingra 2001; Jackson et al. 1995; Park and Smith 2000; De Hart 2014). Consequently, religion brings people together in local congregations and communities that foster social bonds and urge them to volunteer in accordance with the social-religious norm to be compassionate with others in need. The impact of religion on volunteering thus is established through religious social networks rather than through religious believing, although religious social ties could very well by more 'morally freighted' than secular ties, as Putnam 
and Campbell (2010: 477) suspect. However, considering the ongoing process of secularization, the relative shares of these religious communities have decreased over time. Therefore, our third hypothesis reads: Over time the decrease in the proportion of regular churchgoers in the Dutch population has decreased the relative number of volunteers for non-religious organizations $(\mathrm{H} 3)$.

\section{Changes in the Proportion of Highly Educated in the Dutch Population}

For the past decades, Dutch society not only witnessed a process of a massive decline in church attendance, but a process of educational expansion as well (Gesthuizen et al. 2008). The number of highly educated individuals in the Dutch population increased at a sharp rate, which may have increased the number of volunteers in non-religious organizations and thus may have counterbalanced the loss of volunteers due to the decline in the number of regular churchgoers.

There are several reasons why higher educational achievement induces one's likelihood to volunteer. First of all, according to the classic Durkheimian view, the longer children take part in the educational system, the more pro-social norms are instilled in these children. For, according to Durkheim (1984 [1925]), the primary function of education is to transform the selfish child into a social being which values collective interests over individual interests. Today, this is still an important function of the educational system (Hurrelmann 2002). But education not only instills pro-social values, it also enables people to acquire important cognitive competences, like verbal ability (Wiepking and Maas 2009) and reading and writing skills, that improve their qualifications for doing voluntary work. Cognitive competence, therefore, is one of the most important factors explaining the effect of education on volunteering (Gesthuizen and Scheepers 2012). Furthermore, Wilson (2000, 2012) mentions that education also broadens people's horizon, it heightens their awareness of problems and increases empathy. As a result, highly educated people consider society from a more abstract, or cosmopolitan perspective (Gesthuizen and Scheepers 2012), which makes them more aware of the problems and needs of distant others and, subsequently, induces them to volunteer. Given the increasing proportion of highly educated people in the population, our fourth hypothesis, therefore, reads: Over time, the increase in the proportion of highly educated individuals in the Dutch population has increased the proportion of the overall population who volunteer for a non-religious organization (H4). Consequently, on the macro level an increase in the number of highly educated individuals in the Dutch population may have worked as a compensator for the loss due to secularization.

In this study, we thus test four hypotheses concerning different and possible counterbalancing effects of decreasing church attendance rates and educational expansion on non-religious volunteering. The hypotheses are displayed in Fig. 1. 
Longitudinal changes in the behavior of specific groups

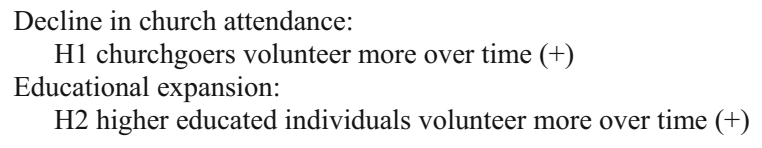

Decline in church attendance:

H1 churchgoers volunteer more over time $(+)$

Educational expansion:

$\mathrm{H} 2$ higher educated individuals volunteer more over time $(+)$

Longitudinal changes in the relative size of specific groups

Decline in church attendance:

H3 less churchgoers over time (-)

Educational expansion:

$\mathrm{H} 4$ more highly educated individuals over time $(+)$

(-) predicts decrease in the rate of volunteers

$(+)$ predicts increase in the rate of volunteers

Fig. 1 Hypotheses to explain the number of volunteers in non-religious organizations in the Netherlands

\section{Method}

\section{Data}

To test our hypotheses, we use data from the 'Cultural Changes' (CV) survey series conducted by the Netherlands Institute for Social Research (SCP). These surveys, all deposited for secondary analyses at Data Archiving and Networked Services (http://www.dans.knaw.nl/nl), aim to detect general patterns and changes over time in opinions of the Dutch population on various social and cultural subjects. As from 1975 onward, these surveys are conducted annually and from 1999 biennially. Each survey is considered to be representative for the Dutch population of 16 years of age and older and contains approximately 2000 respondents. Comparable questions on volunteering were included in the years 1988, 1989, 1996, 1998, 2004, and 2006. For the purpose of this study, we removed missing data and combined the original datasets into a single dataset comprising a total of 11,598 respondents. ${ }^{1}$

\section{Dependent Variable}

Our dependent variable is binomial, indicating whether or not someone volunteered for at least one non-religious organization. Respondents were offered a list of several organizations, including the category 'religious organization,' and were asked to indicate for each organization whether they did volunteer for that

\footnotetext{
${ }^{1}$ Unfortunately, exact figures concerning the response rates for each year are not available. Still, we are confident that differences in response rates need not invalidate our findings. Checking for the possible influence of selective non-response of the data gathered until 1991, Gijsberts (1993) found that although some of the samples of the 'Cultural Changes' survey series differ statistically significant from the Dutch population in view of some general demographic characteristics, it turned out that correcting for these differences by employing weighing techniques did not affect univariate distributions of several target variables used in previous research. Since the method of sampling did not change much for the surveys conducted after 1991, it is conceivable that Gijsbert's conclusion also holds for the datasets we used.
} 
organization or not. Thus, we consider respondents volunteering for at least one of the non-religious organizations mentioned on the list, to be involved in volunteering for non-religious organizations. Unfortunately, the way the respondents' involvement in volunteering was measured varied slightly over the years. To begin with, the number of organizations varied from 4 in the 1998 survey to 14 in the 1988 and 1989 surveys. Nevertheless, in each year the category 'religious organization' was part of the list, which still allows us to make the, for this study, important distinction between religious and non-religious volunteering. A second variation concerns the question posed in the 1998 survey. In this year, the respondents were not asked if they volunteered for the organizations listed at the time of the interview, as in the other surveys, but if they had been a volunteer for these organizations in the past 12 months. Most probably this alternative question resulted in a slightly higher percentage of volunteers for non-religious organizations in 1998. Notwithstanding this difference, we decided to also include the 1998 survey in this study. The 1998 data still allow us to make the important distinction between volunteering for religious and non-religious organizations, and these data can still be used to test our hypotheses, because we will analyze all data per year. This means that including or excluding one particular year does not alter the results found in the other years.

\section{Independent Variables}

Church attendance is measured in all surveys with the following question: "How often do you attend church lately (i.e., during the past 6 months)?" Respondents could choose from the following response categories: 'once a week of more often,' 'once every 2 weeks,' 'once a month,' 'less than once a month,' 'never,' and 'do not know.' The categories 'never' and 'do not know' were combined into 'never.' Respondents attending church at least once every 2 weeks, we consider being regular churchgoers in our descriptive analyses. When we test our hypotheses, we will mainly use the full range of the (five) categories.

Education is measured with the question: "What is the highest level of education you completed?" Through the years, the response categories changed several times due to changes in the Dutch educational system. We recoded the response categories as follows: 'primary education,' 'lower vocational education,' 'junior general secondary education,' 'secondary vocational education,' 'higher education,' and 'university.' Respondents who completed higher education or who have a university degree are considered as the highly educated in our descriptive analyses. When we test our hypotheses, we will mainly use the full range of the (six) categories.

\section{Control Variables}

Included in our study are also the following control variables that are known to be associated with volunteering: sex, age, and marital status (Wilson 2000). With regard to marital status, we distinguished the following categories: 'married,' 'divorced,' 'widow/widower,' and 'unmarried, never been married.' The descriptive statistics of all variables are displayed in Table 1. 
Table 1 Descriptive statistics

\begin{tabular}{lcccc}
\hline Variables & Min & Max & Mean. & SD \\
\hline Volunteer for non-religious organization & .00 & 1.00 & .45 & .50 \\
Church attendance & & & & \\
Once a week or more & .00 & 1.00 & .13 & .34 \\
Once every 2 weeks & .00 & 1.00 & .05 & .21 \\
Once a month & .00 & 1.00 & .06 & .24 \\
Less than once a month & .00 & 1.00 & .19 & .39 \\
Never & .00 & 1.00 & .57 & .50 \\
Education & & & & \\
Primary education & .00 & 1.00 & .08 & .27 \\
Lower vocational education & .00 & 1.00 & .24 & .43 \\
Junior general secondary education & .00 & 1.00 & .12 & .32 \\
Secondary vocational education & .00 & 1.00 & .21 & .41 \\
Higher education & .00 & 1.00 & .23 & .43 \\
University & .00 & 1.00 & .12 & .33 \\
Male & .00 & 1.00 & .47 & .50 \\
Age & 18 & 74 & 43.66 & 14.87 \\
Marital status & & & & .49 \\
Married & .00 & 1.00 & .59 & .27 \\
Divorced & .00 & 1.00 & .08 & .23 \\
Widow/widower & .00 & 1.00 & .05 & .45 \\
Unmarried/never been married & .00 & 1.00 & .27 & \\
\hline Sour: SCP, CV88, CV89, CV96, CV98, & .00 & & \\
\end{tabular}

Source: SCP, CV88, CV89, CV96, CV98, CV04, and CV06. $N=11,598$

\section{Analytical Strategy}

In order to test our hypotheses, we take three steps. First, we consider trends between 1988 and 2006 concerning the proportion of volunteers for non-religious organizations, regular churchgoers and the highly educated in the Dutch population. This not only gives us insight into the development of the rate of church attendance and educational expansion in the Netherlands, but it also shows to what extent the proportion of the Dutch population volunteering for non-religious organizations has been stable during this period. Next we test hypotheses 1 and 2 by considering the expected rise in the relative numbers of volunteers in non-religious organizations among regular churchgoers and highly educated between 1988 and 2006. As a third and final step, we test hypotheses 3 and 4 by performing a counterfactual simulation analysis, which is also known as 'purging' (Te Grotenhuis et al. 2004, Clogg et al. 1990; cf. also the Appendix for a more detailed explanation of this method). This technique enables us to determine the contribution of the decrease of the proportion of churchgoers and increase of the proportion of highly educated to the over time development of the proportion of volunteers in non-religious organizations. In order to calculate the contribution of the decrease of the relative number of churchgoers in this respect, we simulated that church attendance rates did not change since 1988, 
while the process of educational expansion continued. In this way, we answer the following question: What would have been the proportion of volunteers between 1988 and 2006 if rates of church attendance would have been stable on the 1988 level? To measure the impact of the increase of the proportion of highly educated, we simulated educational levels to be constant since 1988, while the decrease of the proportion of churchgoers continued. This enables us to answer the question: What would have been the proportion of volunteers between 1988 and 2006 if the educational levels would not have risen since 1988 ?

To obtain all counterfactual effects, we first run logistic regression analyses for all years separately. In this way, we are able to take into account the changes in the effects over time (cf. Table 2) and the possible effects of a slightly different way of measuring the numbers of volunteers (especially in 1998). All variables are entered into the logistic models as categorical. So, for every category of church attendance, education, age, sex, and marital status a unique (dummy) variable is created with its own effect (expressed as logit estimates) on volunteering. In this way, we take into account possible non-linear relationships. Next, we impose the distributions of church attendance and educational attainment from 1988 on these logit parameters and calculate predicted probabilities to engage in volunteering for non-religious organizations. In a final step, we aggregate these probabilities and calculate the difference between the observed proportion of non-religious volunteers (cf. Table 2) and the predicted proportion under the 1988 distributions. This difference is called the counterfactual effect. The higher this difference, the stronger is the impact of the secularization and educational expansion distribution of church attendance/education over the years. To test whether the counterfactual effects are significant, we calculate the $95 \%$ confidence interval using 1,000 bootstrap samples per model and per year.

\section{Results}

\section{Trends in the Proportion of Volunteers for Non-religious Organizations, Regular Churchgoers, and Highly Educated in the Dutch Population}

Figure 2 clearly shows that both the decline of church attendance as well as the process of educational expansion have continued between 1988 and 2006. In 1988, $22 \%$ of the Dutch still attended church regularly, i.e., at least once every 2 weeks, but by 2006 , this percentage had dropped to $14 \%$. In contrast, the percentage highly educated clearly has increased from $28 \%$ in 1988 to $39.5 \%$ in 2006. Finally, our results reveal that the percentage of volunteers in non-religious organizations has also dropped during this same period. Between 1988 and 1998, this percentage has been fairly stable, with, respectively, 48.4 and $47.4 \%$ of the Dutch population volunteering for a non-religious organization, but after 1998, this figure dropped to $38.4 \%$ in 2006. It seems that the timing of this trend is not in accordance with other research conducted in the Netherlands, which shows that the drop in the number of volunteers set in a few years later (cf. for instance Schuyt et al. 2011). Still, these results do not necessarily have to contradict each other. Because we lack 


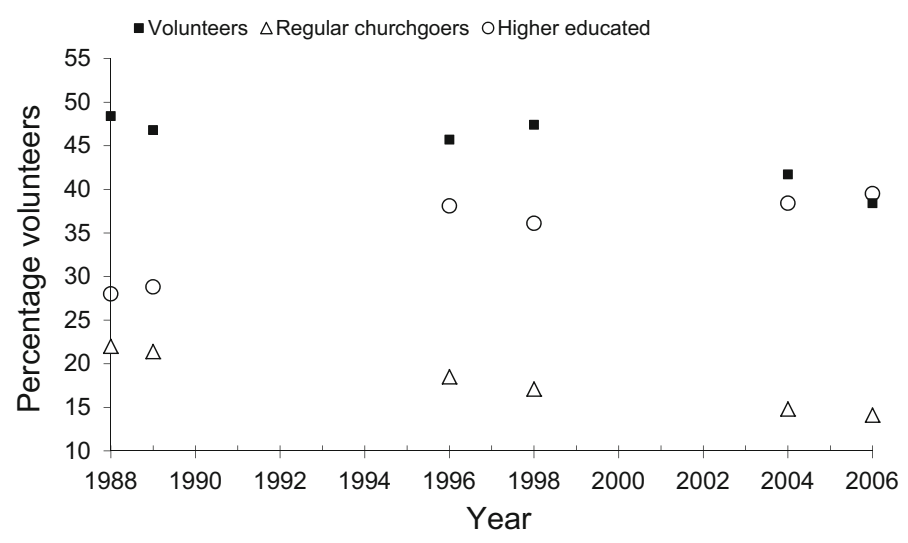

Fig. 2 The percentage volunteers in non-religious organizations (filled square), the percentage regular churchgoers (triangle), and the percentage higher educated (open circle) between 1988 and 2006. Source: SCP, CV88, CV89, CV96, CV98, CV04, and CV06

information between 1998 and 2004, we simply cannot tell exactly when this drop in non-religious volunteering really set in. ${ }^{2}$

Overall these changes thus not fully reflect the trends we expected, since the drop of the number of volunteers for non-religious organizations (minus $10 \%$ points) clearly exceeds the drop of the number of regular churchgoers (minus $8 \%$ points). In contrast, however, the number of highly educated in the Dutch population did increase as expected (plus $11.5 \%$ point). A substantial increase which still makes it plausible to wonder if this latter development perhaps has slowed the decline in nonreligious volunteering.

\section{Trends in the Relative Number of Volunteers for Non-religious Organizations Among Regular Churchgoers and Highly Educated Dutch Between 1988 and 2006}

As we explained in our theoretical section, developments in civic engagement of the Dutch can be the result of behavioral changes within churchgoers and/or the highly educated as well as of changes in the relative sizes of these groups in the Dutch

\footnotetext{
${ }^{2}$ Due to differences in sampling, the percentages of volunteers in the Dutch population reported in various studies are also difficult to compare. For instance, Van Ingen and Dekker (2011) found that only $28 \%$ of the Dutch population is involved in volunteering in 2005, while our data show that more than $38 \%$ of the Dutch are involved in volunteering for non-religious organizations in 2006. However, Van Ingen and Dekker use a sample drawn from the Dutch population of 12 years and older, while our data are gathered among people of 16 years and older. And since teenagers are less involved in volunteering, this could easily explain why our percentage of volunteers is higher. Similarly, Gesthuizen and Scheepers (2012) used data from the 1994-1998 International Adult Literacy Survey (IALS) and report that $42 \%$ of the Dutch are involved in voluntary work, while our data for 1996 and 1998, respectively, show that 46 and $47 \%$ of the Dutch are volunteering for a non-religious organization. But again this difference may be due to the fact that the IALS sample includes people aged 16 to 65, while the samples we use also include people older than 65 , i.e., pensioners with more spare time.
} 
population. In this section, we focus on behavioral changes and test hypotheses 1 and 2. Have regular churchgoers and highly educated indeed become more involved in volunteering for non-religious organizations over time? In addition to this, we also investigate whether similar developments occurred among non-churchgoers and the low educated. In this regard, we consider those Dutch who never attend church to be non-churchgoers and those with lower vocational education to be the low educated.

As Table 2 reveals, between 1988 and 2006, all groups have become less involved in volunteering for non-religious organizations. So, the overall general trend is a decline of civic engagement although there are differences between the various groups. Among non-churchgoers, for example, there is a continuous decline of the relative number of volunteers from $43 \%$ in 1988 to $34 \%$ in 2006, but among regular churchgoers the relative number of non-religious volunteers remains more or less the same until 1996, with 1998 being an outlier probably caused by a slight variation in measurement, and only starts to fall after 1998. Nevertheless, from then on a decrease in the proportion of churchgoers also results in a decrease of volunteering among regular churchgoers. So, the churchgoers have changed their specific voluntary behavior since 1998: they volunteer less for non-religious organizations. Thus we have to reject hypothesis 1 . An over time, ongoing decrease of church attendance does not seem to result in an increasing level of volunteering among the remaining, regular churchgoers. We like to add that the overall statistical association (expressed as an Eta coefficient) between church attendance (5 categories) and volunteering in all years is significant but modest (range between .11 and .19). Similarly, we also have to reject hypothesis 2 , which predicts an increase of civic engagement among the highly educated as a result of educational expansion in the Netherlands. To the contrary, as shown in Table 2, over time there has been a continuous decline in the relative number of highly educated volunteers from $54 \%$ in 1988 to $43 \%$ in 2006, although for each year the relative number of highly educated volunteers is still substantially higher than the relative number of low educated volunteers. So, although there is indeed a positive association between education and volunteering for non-religious organizations, the highly educated have not changed their voluntary behavior in the way we expected. This is also

Table 2 Non-churchgoing, churchgoing, lower educated, and higher educated volunteers for non-religious organizations between 1988 and $2006(\%)$ plus Eta statistic [using all categories of church attendance (5) and education (6)]

\begin{tabular}{lcccccc}
\hline & 1988 & 1989 & 1996 & 1998 & 2004 & 2006 \\
\hline Non-church-goers & 43 & 42 & 40 & 40 & 38 & 34 \\
Regular churchgoers & 55 & 54 & 56 & 63 & 52 & 50 \\
Eta church attendance & .12 & .11 & .15 & .19 & .11 & .15 \\
Lower educated & 40 & 37 & 30 & 38 & 33 & 28 \\
Higher educated & 54 & 54 & 51 & 51 & 44 & 43 \\
Eta Education & .14 & .13 & .14 & .07 & .06 & .10 \\
\hline
\end{tabular}

Data source: SCP, CV88, CV89, CV96, CV98, CV04, and CV06 
reflected in a significant but fairly low Eta coefficient (between .14 and .06), which tends to slightly decrease over the years. ${ }^{3}$

\section{Counterfactual Analysis: Simulating Constant Church Attendance Rates and Educational Levels Since 1988}

Developments in volunteering may also be due to changes in the proportion of churchgoers and highly educated in the Dutch population. This explanation is subject of hypotheses 3 and 4. Hypothesis 3 states that a drop in regular churchgoers has resulted in a decrease of the number of volunteers, while hypothesis 4 states that an increase of the highly educated has led to an increase of the number of volunteers for non-religious organizations. As we already mentioned above, we test these hypotheses by performing a counterfactual simulation analysis using three models. In model 1, we estimate the counterfactual effects of the decrease of regular churchgoers and the increase of the highly educated separately. In model 2, we estimate the effects simultaneously, and in model 3, the effects again are obtained simultaneously but now we control for age, sex, and marital status. The main results can be found in Table 3 .

In model 1, we estimated the gross effect of the longitudinal shifts in the proportion of churchgoers and highly educated people. Both shifts have the hypothesized effect: if church attendance rates would have been stable since 1988, then in the subsequent years (except 1989), the percentage of volunteers would have been significantly higher than the actual percentage of volunteers. If the educational levels would have been stable since 1988, then the percentage of volunteers would have been significantly lower in 1996, 1998, 2004, and 2006. The $95 \%$ confidence intervals give useful insight into the difference within the population as a whole. ${ }^{4}$

\footnotetext{
3 In an additional analysis, we also considered trends regarding volunteering for a religious organization. Findings show that relatively more churchgoers volunteer for a religious organization over time, from $36 \%$ in 1988 to $48 \%$ in 2006, which also resulted in an increase of the overall statistical association between church attendance and religious volunteering from .45 in 1988 to .51 in 2006 . However, such a trend does not occur among the low or highly educated. The proportion of both the low and highly educated involved in religious volunteering remains fairly stable at $10 \%$ between 1988 and 2006. As a result, the overall statistical association between education and volunteering for a religious organization remains very weak and non-significant during this period. The strongest association between education and volunteering for a religious organization is in the years 1996 and 1998 with an Eta coefficient of only .03. This offers empirical support for the theoretical assumption we already mentioned in the introduction; viz. that it is unlikely that highly educated become more involved in volunteering for religious organizations. Consequently, our decision to distinguish between volunteering for religious and non-religious organizations and to only study the counterbalancing effects of education and church attendance for volunteering for non-religious organizations indeed turns out to be the best possible strategy. It is impossible that educational expansion will counterbalance the loss of volunteers for religious organizations due to a decline of church attendance, because there is no association between education and volunteering for a religious organization.

4 For instance, the effect of the drop in church attendance rates in the Netherlands was most probably between 1.02 and $2.62 \%$ in 1998. For the rise in educational levels the effect was most probably between -2.09 and $-.48 \%$ in that same year. If we take a look at all $95 \%$ confidence intervals then we must conclude that the effects are not very strong: there is a counterbalancing effect of the drop in church attendance rates and the rise educational levels but the effects are small.
} 


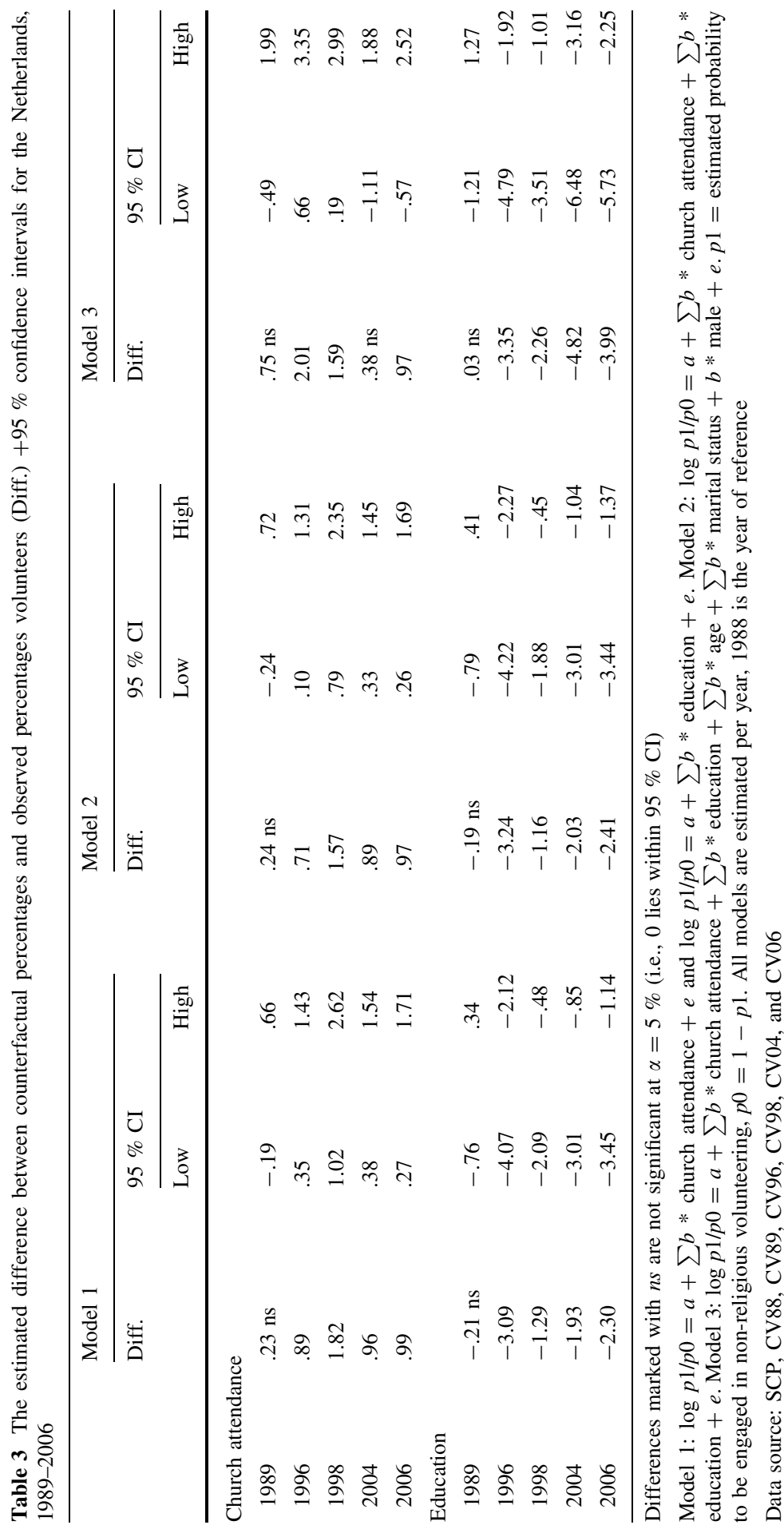


One may object to this analysis that the counterbalancing effect is more accurate measured when the effects are estimated simultaneously in a multivariate model, see Model 2. Again the counterfactual effects are as expected (save 1989) but again the effects are not very strong. In our final model (model 3), we tried to come closer to the causal effect by controlling for possibly confounding variables that are both related to volunteering on the one hand and church attendance and education on the other hand, namely age, marital status, and sex.

The results of our third model, in which we controlled for the effects of sex, age, and marital status, are also displayed in Fig. 3. This figure clearly shows the modest (often non-significant) effects of the decrease of church attendance and the somewhat stronger effects of the increasing educational levels. Over time decreases in the relative numbers of churchgoers indeed seems to decrease the relative numbers of volunteers for non-religious organizations. That is to say, if the level of church attendance had not fallen after 1988, the percentage of volunteers in nonreligious organizations in 1989, 1996, 1998, 2004, and 2006 would, respectively, have been 0.75 (not significant), 2.0, 1.6, 0.4 (not significant), and 1.0 (not significant) percent points higher than the actual percentage. The process of educational expansion, in contrast, increases volunteering for non-religious organizations. If the overall educational level of the Dutch population would not have risen after 1988, the relative numbers of volunteers in non-religious organizations would have been virtually the same in 1989, but in 1996, 1998, 2004, and 2006 it would, respectively, have been 3.4, 2.3, 4.8, and $4.0 \%$ points lower than the actual percentage. These findings confirm both hypothesis 3 and 4 . A decline in the proportion of churchgoers indeed has a negative effect on the relative share of the Dutch population volunteering for non-religious organizations, while the increase of the proportion of highly educated people has more than

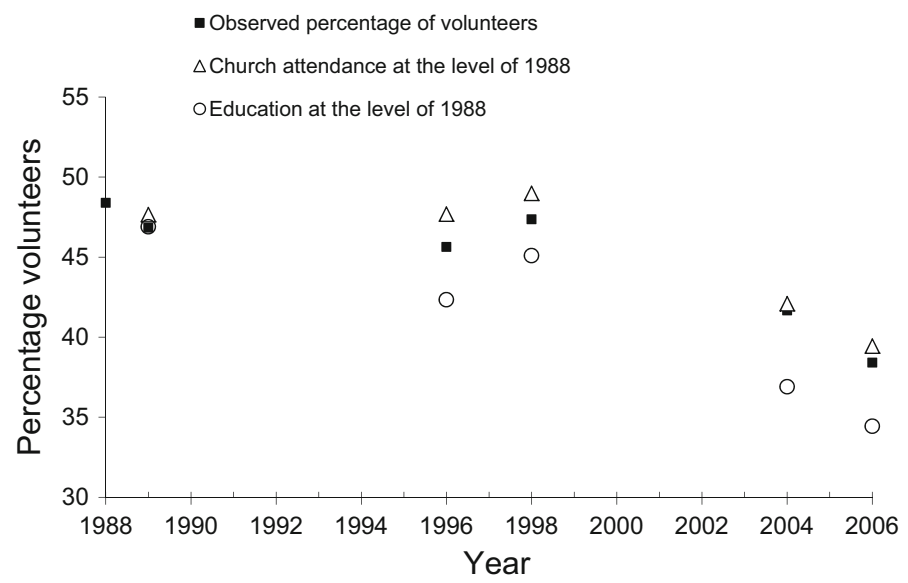

Fig. 3 The observed percentage of volunteers (filled square), the percentage of volunteers if church attendance rates had not declined after 1988 (triangle), and the percentage of volunteers if the educational levels had not increased after 1988 (open circle). Simulations are controlled for sex, age, and marital status. Data source: SCP, CV88, CV89, CV96, CV98, CV04, and CV06 
counterbalanced these losses. However, this latter process of educational expansion has not stopped the gradual longitudinal decline in volunteering for non-religious organizations. In sum, we can conclude that the loss of volunteers in the nonreligious sector is only marginally due to a decrease in church attendance, while educational expansion, with increasing shares of highly educated people, has compensated this (marginal) loss.

\section{Conclusion and Discussion}

In this study, we addressed the following research question: Why has the massive decline of church attendance in the Netherlands not resulted in a similar substantial drop in the relative number of volunteers in non-religious voluntary organizations? In view of this question, we investigated whether the loss of volunteers in nonreligious organizations as a result of declining church attendance rates perhaps was compensated by an increase of highly educated people.

To begin with, we found no evidence of behavioral changes within the group of churchgoers and highly educated in the population, at least not in the way we expected. Against our expectations, regular churchgoers and the highly educated have over the years become less, rather than more, involved in non-religious voluntary work. Next to the effects of these behavioral changes, we also considered effects of secularization and educational expansion within the Dutch population. Although composition effects have indeed occurred, our results also show that they have been very modest. The gradual over time decline of church attendance rates in the Dutch population has indeed limited the number of volunteers in non-religious organizations, while an over time increase of educational levels has increased the number of volunteers in these organizations. In addition, the counterbalancing effect of educational expansion is clearly stronger than the effect of the decrease of church attendance, but it was not strong enough to stop the overall trend of a slightly declining number of volunteers in non-religious organizations. Thus we conclude that the gradual decline of volunteers in non-religious organizations is not so much due to the changing composition of the Dutch population, but due to behavioral change, i.e., even groups known for their civic engagement, like regular churchgoers and highly educated, volunteer less over time.

In this way, our focus on volunteering for non-religious organizations has actually yielded somewhat different results than the earlier study by Van Ingen and Dekker (2011). They also studied the balancing effects of declining church attendance and educational expansion without, however, making a clear distinction between volunteering for secular and religious organizations or performing a counterfactual analysis. Thus they report a strong increasing effect of church attendance on volunteering over the years, whereas our results show that the effect of church attendance is indeed positive though very modest. In this respect, our results are more in line with the results of the additional analysis of Van Ingen and Dekker in which they focused on secular volunteering. Moreover, the increasing, though still modest, effect of educational expansion we found differs from the declining effect of education reported by Van Ingen and Dekker. But also this 
difference could very well be due to the fact that we focus on volunteering for nonreligious organizations, whereas Van Ingen and Dekker did not. These differences again underscore the importance of making a clear distinction between volunteering for non-religious and religious organizations while studying possible counterbalancing effects of declining church attendance and educational expansion, as this may indeed affect the results.

Notwithstanding our focus on volunteering for non-religious organizations, the composition effects we found are rather modest. With regard to these effects, two remarks are in place here. Not only is the period covered by our longitudinal data relatively short as compared to previous studies, but it is also a period in which the decrease of church attendance was already well advanced (Bernts et al. 2007; Statistics Netherlands 2009). Therefore, we cannot rule out that the composition effects are stronger in previous periods we could not cover. The data we used from the 'Cultural Changes' survey series contain information on the level of church attendance of the Dutch back to 1975, but questions on volunteering were included for the first time in the 1988 survey. A second remark concerns the measurement of our dependent variable: volunteering for non-religious organizations. In this respect, we considered all forms of voluntary work not done for a religious organization as instances of secular volunteering. However, one may wonder whether church attendance is equally important for all kinds of voluntary work ranging, for example, from giving aid to disabled people to volunteering for a sports club (Wilson 2000). Therefore, we again cannot rule out that the behavioral and composition effects are in part also influenced by this rather crude measurement of volunteering for non-religious organizations. Or, to put this otherwise, the trends in civic engagement of regular churchgoers and the highly educated as well as the composition effects, we found could very well be different depending on the type of secular, voluntary work. However, as we also explained above, due to slight variations in the questions posed in the surveys, volunteering for non-religious organizations could not be further specified. Despite these potential shortcomings, we regard our findings to reveal important developments in Dutch civil society.

In line with previous research, our findings again show that involvement in a religious community is an important source of civic engagement (Wilson 2000). Despite the fact that the number of regular churchgoers who volunteer for a nonreligious organization decreased with $5 \%$ points between 1988 and 2006, in 2006 still $50 \%$ of the regular churchgoers is actively involved in a non-religious organization. This percentage becomes even more important, if we realize that among non-churchgoers 'only' $34 \%$ volunteers for a non-religious organization. Also a comparison with the percentages of the highly educated volunteering for a non-religious organization adds to the importance of these figures. In 1988, the percentages of regular churchgoers and highly educated volunteering for a nonreligious organization were almost equal, i.e., 55 and $54 \%$, respectively, but by 2006 these respective percentages were 50 and $43 \%$ and so the difference had increased from 1 to $7 \%$ points. Although these percentages show that the relative number of volunteers among both the regular churchgoers and the highly educated has decreased over time, which forced us to reject hypothesis 1 and 2, they also show that this decrease is less among regular churchgoers than among highly 
educated. It seems, therefore, that among regular churchgoers civic engagement is more stable than among highly educated. Although we have to keep in mind that in absolute numbers there are, of course, far more highly educated volunteers than churchgoing volunteers.

As regards the future of Dutch civil society, the findings of this study thus give reason to concern. For, not only is there a decrease in the number of regular churchgoers in the Netherlands, the average age of this specific group also increases (Becker and De Hart 2006). Consequently, the number of regular churchgoers willing and able to engage in voluntary work is likely to decrease in the near future, which probably means that an apparently still important source of civic engagement is about to become exhausted. At present, regular churchgoers are still far more civically active than non-churchgoers (De Hart 2014), but what will happen when older religiously committed birth cohorts are gradually being replaced by younger more secular birth cohorts? In addition, as we have seen above, among the regular churchgoers the relative number of volunteers in non-religious organizations also decreases. Although the drop is less than among the highly educated, the trend is nevertheless downward. We cannot tell exactly why this is the case. But looking at the trends regarding volunteering for religious organizations (cf. note 3), we assume that regular churchgoers volunteer more for their own religious community at the cost of their civic engagement. Thus, contrary to our first hypothesis, in times of declining rates of church attendance churchgoers apparently become more dedicated to the survival of their own religious community, which in turn decreases the odds that their religious voluntary actions spillover into non-religious volunteering. Or to put this in terms of Putnam (2000), in times of religious decline, 'bonding' social capital may become more important than 'bridging' social capital, which eventually limits the voluntary engagement of regular churchgoers in non-religious organizations. So, given the fact that our study again reveals that involvement in a religious community is an important determinant of people's civic engagement, also for nonreligious causes, it at the same time suggests that the future of Dutch civil society may not look very bright.

However, the fact that the civic engagement among regular churchgoers seems more stable than among the highly educated does not mean that educational expansion is irrelevant for the future of Dutch civil society. Although the composition effects revealed by our study are rather modest, these effects nevertheless show that educational expansion does compensate for the loss of volunteers in non-religious organizations. In addition, this positive effect of educational expansion even appears to be stronger than the negative effect of declining rates of church attendance. Educational expansion thus also remains an important factor in the maintenance of Dutch civil society. And we have reason to believe, that educational expansion continues to be of importance in this respect even when upward educational mobility probably reaches its limits in the near future.

Next to resulting in expanding social networks of highly educated, educational expansion may also result in a specific socialization effect. For, due to educational expansion, the average level of education of the Dutch population has risen to such an extent that civic engagement has become a general, societal norm and no longer a 
norm shared especially among the highly educated (Gesthuizen et al. 2008). A development which may affect the socialization experiences of younger birth cohorts. Because younger birth cohorts now grow up in a highly educated context, they at the same time internalize the social norm to contribute to the common good through voluntary action. Such a basic experience during the formative years of adolescence may have a lasting effect on the identity and social orientations of present-day youths (Vollebergh et al. 2001), which in turn increases the likelihood that they get involved in voluntary action as adults even if they themselves do not have a higher education or university degree. So, if this socialization effect really occurs among the younger birth cohorts, the slowing down of educational expansion need not necessarily lower the number of volunteers.

What the future of Dutch civil society will be? remains an open question. Until today, churches have been and still are a very important source of formal social capital, but it is likely that this source will run dry in the very near future. Hopefully, therefore, educational expansion has indeed resulted in a societal context in which voluntary action for the benefit of others is the general norm.

Open Access This article is distributed under the terms of the Creative Commons Attribution 4.0 International License (http://creativecommons.org/licenses/by/4.0/), which permits unrestricted use, distribution, and reproduction in any medium, provided you give appropriate credit to the original author(s) and the source, provide a link to the Creative Commons license, and indicate if changes were made.

\section{Appendix: the Method of Purging; Simulating a Fixed Distribution}

In this article, we used the statistical method of purging to estimate the consequences of changes in the proportion of churchgoers and highly educated in the Dutch population for the relative number of volunteers in non-religious organizations in the Netherlands between 1988 and 2006. To explain the basic principles of this method, we provide an example with two by two tables. In these tables, we use a dichotomy of education (lower/middle vs. higher). We first describe the situation in 1988 (our baseline). According to our 1988 sample, $60.2 \%$ of the Dutch had a low or middle education and $39.8 \%$ had enjoyed a higher education (see Table 4). Within the highly educated respondents, the percentage of volunteers

Table 4 The relationship between non-religious volunteering and education in the Netherlands, 1988

\begin{tabular}{llll}
\hline & Low/middle education & High education & Row totals \\
\hline No volunteer & 438 & 230 & 668 \\
Volunteer & $57.1 \%$ & $45.3 \%$ & $52.4 \%$ \\
Column totals & 329 & 278 & 607 \\
& $42.9 \%$ & $54.7 \%$ & $47.6 \%$ \\
& 767 & 508 & 1275 \\
\hline
\end{tabular}

Strength of association in Cramér's $V=.12$

Data source: SCP, CV88 
for non-religious organizations was $54.7 \%$ and it amounted to $42.9 \%$ within the low/middle educated. In total, $47.6 \%$ of the sample was a volunteer for nonreligious organizations.

Almost twenty years later the situations looks different (see Table 5). The educational distribution changed considerably; the percentage of low/middle educated respondents went down to $38.2 \%$ and the share of higher educated raised to $61.8 \%$. Interestingly, the relative shares of volunteers dropped with almost the same rate to $30.7 \%$ among the low/middle educated and to $41.7 \%$ among the highly educated. The statistical association, therefore, virtually remained the same (Cramér's $V=.11$ in 1988 and Cramér's $V=.12$ in 2006). In total, the percentage of volunteers for non-religious organizations dropped to 37.5 in 2006.

The question we answered in this article is whether the observed shift in the proportion of highly educated between 1988 and 2006 is related to the trend in nonreligious volunteering. As higher educated people are observed to have a higher prevalence for non-religious volunteering than the lower and middle educated, the observed increase in the proportion of higher educated people in the Netherlands must be associated with a rise in the proportion of volunteers for non-religious organizations. To assess the magnitude and significance of this rise, we simulated a counter factual situation in which we imposed the 1988 distribution of education

Table 5 The relationship between non-religious volunteering and education in the Netherlands, 2006

\begin{tabular}{llll}
\hline & Low/middle education & High education & Row totals \\
\hline no volunteer & 312 & 424 & 736 \\
Volunteer & $69.3 \%$ & $58.3 \%$ & $62.5 \%$ \\
& 138 & 303 & 441 \\
Column totals & $30.7 \%$ & $41.7 \%$ & $37.5 \%$ \\
& 450 & 727 & 1177 \\
\hline
\end{tabular}

Strength of association in Cramér's $V=.11$

Data source: SCP, CV88

Table 6 The simulated relationship between non-religious volunteering and education in the Netherlands, with the 1988 distribution of education and the 2006 association and sample size

\begin{tabular}{llll}
\hline & Low/middle education & High education & Simulated row totals \\
\hline No volunteer & 491 & 273 & 764 \\
& $69.3 \%$ & $58.3 \%$ & $64.9 \%$ \\
Volunteer & 218 & 195 & 413 \\
Column totals & $30.7 \%$ & $41.7 \%$ & $35.1 \%$ \\
& 709 & 468 & 1177 \\
& $60.2 \%$ & $39.8 \%$ & $100 \%$ \\
\hline
\end{tabular}

Strength of association in Cramér's $V=.11$

Data source: SCP, CV 1988/2006 
together with the 2006 association between education and non-religious volunteering upon the 2006 sample (see Table 6).

In Table 6, the column total percentages for the low/middle educated and the highly educated (60.2 and 39.8) are from 1988. When applied to the 2006 sample size of 1177 , we get the new column totals of 709 and 468 . In the inner cells, the percentages from 2006 can be found $30.7 \%$ of the low/middle educated and $41.7 \%$ of the highly educated are non-religious volunteers). With this, we can calculate the new absolute numbers in the inner cells. We have 218 non-religious volunteers among the low/middle educated (calculation: $.307 \times 709$ ) and 195 within the highly educated. Finally, we summed both numbers and calculated the simulated percentage of non-religious volunteers. This amounted to $35.1 \%$ $((218+195) / 1177)$. So, if the 1988-2006 increase in the proportion of highly educated people would not have taken place, then the percentage of non-religious volunteers would have been 35.1 and not 37.5. This means that as far as the percentage of non-religious volunteers in 2006 is concerned, educational expansion is associated with a rise of $2.4 \%$ points (37.5-35.1). Of course this is a sample result, and in the population it could be different. To compute the interval of possible outcomes, we used bootstrapping in which all percentages in Table 3 were treated as random variables. The $95 \%$ confidence intervals were computed and can be found in the main text. Needless to say, we used the same statistical method for estimating the consequences of educational expansion for the relative numbers of volunteers in non-religious organizations for the years 1989, 1996, 1998, and 2004.

\section{References}

Becker, J., \& De Hart, J. (2006). Godsdienstige veranderingen in Nederland. Verschuivingen in de binding met de kerken en de christelijke traditie. Den Haag: SCP.

Becker, P. E., \& Dhingra, P. H. (2001). Religious involvement and volunteering: Implications for civil society. Sociology of Religion, 62(3), 315-335.

Bekkers, R. (2004). Giving and volunteering in the Netherlands: Sociological and psychological perspectives. Utrecht: Utrecht University.

Bekkers, R., \& Schuyt, T. (2008). And who is your neighbor? Explaining denominational differences in charitable giving and volunteering in the Netherlands. Review of Religious Research, 50(1), 74-96.

Berger, I. E. (2006). The influence of religion on philanthropy in Canada. Voluntas 17, 115-132.

Bernts, T., Dekker, G., \& De Hart, J. (2007). God in Nederland 1996-2006. Ten Have: Kampen.

Bruce, S. (2003). The demise of christianity in britain. In G. Davie, P. Heelas, \& L. Woodhead (Eds.), Predicting religion. Christian, secular and alternative futures, Aldershot: Ashgate.

Clogg, C. C., Shockey, J. W., \& Eliasen, S. R. (1990). A general statistical framework for adjustment of rates. Sociological Methods and Reseach, 19(2), 156-195.

Data Archiving and Networked Services https://easy.dans.knaw.nl/ui/?wicket:bookmarkablePage=:nl. knaw.dans.easy.web.search.pages.PublicSearchResultPage \&q=culturele\%20veranderingen.

De Graaf, N. D., \& Te Grotenhuis, M. (2008). Traditional Christian belief and belief in the supernatural: Diverging trends in the Netherlands between 1979 and 2005? Journal for the Scientific Study of Religion, 47(4), 585-598.

De Hart, J. (1999). Godsdienst, maatschappelijke participatie en sociaal kapitaal. Nederland in internationaal en historisch perspectief. In P. Dekker (Ed.), Vrijwilligerswerk vergeleken. Den Haag: SCP.

De Hart, J. (2014). Geloven binnen en buiten verband. Godsdienstige ontwikkelingen in Nederland. Den Haag: SCP. 
Dekker, P., \& Van den Broek, A. (2005). Involvement in voluntary associations in North America and Western Europe: Trends and correlates 1981-2000. Journal of Civil Society, 1(1), 45-59.

Durkheim, E. (1984) [1902]. Erziehung, Moral und Gesellschaft, Frankfurt a.M., Suhrkamp

Gesthuizen, M. (2006). How socially committed are the Dutch low-educated? Historical trends, lifecourse changes, and two explanations for educational differences. European Sociological Review, 22(1), 91-105.

Gesthuizen, M., \& Scheepers, P. (2012). Educational differences in volunteering in cross-national perspective: Individual and contextual explanations. Nonprofit and Voluntary Sector Quarterly, $41(1), 58-81$.

Gesthuizen, M., Scheepers, P. Van, der Veld, W., \& Völker, B. (2013). Structural aspects of social capital: Tests for cross-national equivalence in Europe. Quality \& Quantity, 47(2), 909-922.

Gesthuizen, M., Van der Meer, T., \& Scheepers, P. (2008). Education and dimensions of social capital: Do educational effects differ due to educational expansion and social security? European Sociological Review, 24(5), 617-632.

Gijsberts, M. (1993). Culturele veranderingen: het wegen waard? Rijswijk: SCP.

Glock, C. Y., \& Stark, R. (1965). Religion and society in tension. Chicago: Rand McNally.

Herweijer, L. (2010). Generaties in het onderwijs en op de arbeidsmarkt. In A. van den Broek, R. Bronneman-Helmers, \& V. Veldheer (eds.), Wisseling van de wacht: Generaties in Nederland. Sociaal en Cultureel Rapport 2010, Den Haag: SCP.

Hurrelmann, K. (2002). Einführung in die Sozialisationstheorie. Beltz: Weinheim/Basel.

Jackson, E. F., Bachmeier, M. D., Wood, J. R., \& Craft, E. A. (1995). Volunteering and charitable giving: Do religious and associational ties promote helping behaviour? Nonprofit and Voluntary Sector Quarterly, 24(1), 59-78.

Kelley, D. M. (1972). Why conservative churches are growing. A study in sociology of religion. New York: Harper \& Row.

Park, J. Z., \& Smith, C. (2000). "To whom much has been given...”: Religious capital and community voluntarism among churchgoing protestants. Journal for the Scientific Study of Religion, 39(3), 272-286.

Perks, Th, \& Haan, M. (2011). Youth religious involvement and adult community participation: Do levels of youth religious involvement matter? Nonprofit and Voluntary Sector Quarterly, 40(1), 107-129.

Pichler, F., \& Wallace, C. (2007). Patterns of formal and informal social capital. European Sociological Review, 23(4), 423-435.

Putnam, R. D. (2000). Bowling alone. The collapse and revival of American community. New York: Simon \& Schuster.

Putnam, R. D. and Campbell, D. E. (2010). American grace. How religion divides and unites us. New York: Simon \& Schuster.

Reitsma, J. (2007). Religiosity and solidarity. Dimensions and relationships disentangled and tested. Nijmegen: Radboud University Nijmegen.

Ruiter, S., \& De Graaf, N. D. (2006). National context, religiosity, and volunteering: Results from 53 countries. American Sociological Review, 71(2), 191-210.

Savelkoul, M., Gesthuizen, M., \& Scheepers, P. (2011). Explaining relationships between ethnic diversity and informal social capital across European countries and regions: Tests of constrict, conflict and contact theory. Social Science Research, 40, 1091-1107.

Schuyt, Th, Gouwenberg, B., \& Bekkers, R. (2011). Giving in the Netherlands: donations, bequests, sponsorship and volunteering. Amsterdam: Reed Business.

Smith, D. H. (1994). Determinants of voluntary association participation and volunteering: A literature review. Nonprofit and Voluntary Sector Quaterly, 23(3), 243-263.

Statistics Netherlands. (2009). Religie aan het begin van de 21ste eeuw. Den Haag: CBS.

Te Grotenhuis, M., Eisinga, R., \& Scheepers, P. (2004). The method of purging applied to repeated cross national data. Practical applications using logistic and linear regression analyses. Quality \& Quantity, 38(1), 1-16.

Van Ingen, E., \& Dekker, P. (2011). Changes in the determinants of volunteering: Participation and time investment between 1975 and 2005. Nonprofit and Voluntary Sector Quaterly, 40(4), 682-702.

Van Tienen, M., Scheepers, P., Reitsma, J, \& Schilderman, H. (2011). The role of religiosity for formal and informal volunteering in the Netherlands. Voluntas, 22, 365-389.

Vermeer, P., \& Janssen, J. (2011). Belonging and believing among Dutch forty-year -olds: A panel study. Journal of Empirical Theology, 24(1), 57-79. 
Vollebergh, W., Iedema, J., \& Raaijmakers, Q. (2001). Intergenerational transmission and the formation of cultural orientations in adolescence and young adulthood. Journal of Marriage and Family, 63(4), 1185-1198.

Wiepking, P., \& Maas, I. (2009). Resources that make you generous: Effects of social and human resources on charitable giving. Social Forces, 7(4), 1973-1995.

Wilson, J. (2000). Volunteering. Annual Review of Sociology, 26, 215-240.

Wilson, J. (2012). Volunteerism research: A review essay. Nonprofit and Voluntary Sector Quaterly, 41(2), 176-212. 